\title{
SÕNA ESINEMISSAGEDUS JA TÄHENDUSTE ERISTAMISE VAJADUS HÄÄLDUSE MÕJUTAJANA
}

\author{
Mari-Liis Kalvik ja Liisi Piits \\ Eesti Keele Instituut
}

\begin{abstract}
Ülevaade. Artikkel käsitleb kaht eesti keeles varieeruvat nähtust: $h$ hääldamist sõna alguses ning $i$-tüveliste (C)VVC-struktuuriga sõnade lõpukonsonantide palatalisatsiooni. Mõlema nähtuse puhul uuritakse, milline on sõna esinemissageduse ning tähenduste eristamise vajaduse mõju hääldusele. Uurimismaterjaliks on $42 h$-algulist sõna ja 30 pika vokaaliga ühesilbilist $i$-tüvelist sõna, mis on keelejuhtide poolt ette loetud. 94 keelejuhi 3945 hääldusjuhu uurimine andis tulemuseks, et a) $h$ väljahääldamine oli valdav ( $92 \%$ juhtudest); b) suurema esinemissagedusega sõnades oli sõnaalguline $h$ enamasti lühem ja see jäeti välja hääldamata sagedamini kui väiksema esinemissagedusega sõnades; c) esines tendents, et sõnades, kus $h-1$ on tähendust eristav ülesanne, oli $h$ veidi sagedamini ja veidi pikemalt välja hääldatud. 40 keelejuhi 1280 hääldusjuhu analüüs näitas, et a) väiksema esinemissagedusega sõnu ei palataliseeritud märgatavalt vähem kui suurema esinemissagedusega sõnu ning b) sõnu, kus palatalisatsiooni esinemine eristab tähendusi, palataliseeriti rohkem.
\end{abstract}

Märksõnad: sõnaalguline $h$, palatalisatsioon, esinemissagedus, tähenduste eristamine, lugemiseksperiment, kestus

DOI: https://doi.org/10.12697/jeful.2019.10.1.04

\section{Sissejuhatus}

Artiklis uuritakse sõna esinemissageduse ja tähenduste eristamise vajaduse mõju kahele eesti keeles varieeruvale nähtusele: sõnaalgulise $h$ hääldusele ja palatalisatsiooni esinemisele (C)VVC-struktuuriga $i$-tüvelistes sõnades.

Sõnaalgulise $h$ kirjutamine põhineb ajaloolistel kokkulepetel, kuid selle väljahääldamine on tänapäeval kujunenud vabaks. „Eesti õigekeelsuskäsiraamatus“ selgitatakse, et „h kirjutamine sõna algul on traditsioonipärane, häälduses ei ole see nõutav“ (Mäearu 2014-2018). Varasemad uurimused on toonud esile, et $h$ hääldamine on seotud ametliku situatsiooniga, mispuhul hääldatakse sõnaalguline $h$ märgatavalt 
rohkem välja (Cui 1999, Mesipuu 2007). Neid tulemusi kinnitab ka eesti keele spontaanse kõne foneetilise korpuse ${ }^{1}$ materjal. Korpuse põhjal tehtud uurimuste tulemustest on selgunud, et kui keskmiselt on $h$ sõna alguses välja hääldatud $46 \%$ kõigist juhtudest, siis ametlikumates monoloogides on seda tehtud 76\% hääldusjuhtudest (Asu et al. 2016: 115). Väikses etteloetud kõnel põhinevas uurimuses on varem leitud, et loetud kõnes on $h$ väljahääldamise protsent veelgi kõrgem, keskmiselt 95\% (Kalvik ja Piits 2015: 65).

Sõna esinemissagedust on nähtud eelkõige häälduskestuse mõjutajana (Bell et al. 2009) ja häälikukao põhjustajana (Coetzee ja Kawahara 2013, Bybee 2002). Varasemates eesti keele kohta tehtud sõnaalgulise $h$ uuringutes on tähele pandud, et suurema esinemissagedusega sõnades jääb häälik sagedamini välja hääldamata kui väiksema esinemissagedusega sõnades (Cui 1999: 42). Siinses uurimuses tahtsimegi esmalt välja selgitada, kas sagedates sõnades on $h$ kestus lühem ja kas seda jäetakse rohkem välja hääldamata kui harvades sõnades.

Eesti keeles üldjuhul ei ole rangelt fikseeritud hääldusstandardit (Asu et al. 2016: 11), siiski märgib kirjakeele normi alus „Eesti õigekeelsussõnaraamat ÕS 2018“ rõhu ja välte kõrval ka palatalisatsiooni. Hiljutine uurimus (Piits ja Kalvik 2019) tegi kindlaks, et ÕS-is palatalisatsioonimärgi saanud (C)VVC-struktuuriga $i$-tüveliste sõnade lõpukonsonantide $(l, n, s, t / d)$ palataliseerimine on igapäevases keelekasutuses ebajärjekindel. Kokkuvõtlikult öeldes on selles tüübis valdav palatalisatsioonita hääldus. Käesolevas uurimuses soovisime teada saada, kas palatalisatsiooni esinemine on seni käsitletud tegurite kõrval mõjutatud ka sõna esinemissagedusest.

Lisaks oletasime, et kummagi nähtuse puhul võib varieerumine sõltuda ka sellest, kas konkreetses sõnas on sellel häälikul tähendust eristav funktsioon või mitte. Sõnaalguline $h$ ja palataliseeritud häälik võivad esineda nii sõnades, kus nad eristavad tähendusi (nt haru 'tervikust hargnev iseseisev osa' vs. aru 'mõistus' ja noot'2 'noodikirjamärk' vs. noot 'kalapüügivahend') kui ka sõnades, kus nad tähendusi ei erista. Tähele on pandud, et suurema naabrustihedusega sõnu ehk sõnu, millest ühe foneemi asendamisega on võimalik moodustada rohkem tähenduslikke tähejärjendeid, hääldatakse välja püüdlikumalt (Vitevitch ja Luce

1 Vt https://www.keel.ut.ee/et/foneetikakorpus.

2 Kriipsuke konsonandi järel märgib palataliseeritud häälikut. 
2016). Me ei ole uuritavate sõnade puhul välja arvutanud, milline oleks nende naabrustihedus ehk kui palju täistähenduslikke sõnu tekiks ühe foneemi asendamisel teisega. Selle asemel oleme vaadanud, kuidas mõjutab hääliku hääldamist see, kas ta täidab fonoloogilist funktsiooni, st kas sõnaalgulise $h$ hääldamata jätmine või lõpukonsonandi mittepalataliseerimine tekitab uue tähendusega sõna. Seega oleme materjalist välja otsinud sõnad, kus sõnaalguline $h$ või palataliseeritud konsonant eristab tähendusi. Meid huvitas, kas tähendusi eristavatel juhtudel hääldatakse häälik püüdlikumalt välja. $h$ puhul jälgisime, kas sellistel juhtudel hääldatakse $h$ rohkem välja ja kas $h$ kestus on siis pikem kui tähendusi mitteeristavatel juhtudel. Palatalisatsiooniga seoses vaatasime vaid selle esinemist või mitteesinemist.

Püstitasime järgmised uurimisküsimused:

1. Kas suurema esinemissagedusega sõnades on sõnaalguline $h$ lühem ja kas see jäetakse sagedamini välja hääldamata kui väiksema esinemissagedusega sõnades?

2. Kas väiksema esinemissagedusega, keelejuhile eeldatavasti tundmatumaid sõnu palataliseeritakse vähem kui suurema esinemissagedusega sõnu?

3. Kas sõnades, kus sõnaalgulise $h$ või palataliseeritud hääliku esinemine eristab tähendusi, hääldatakse vastav häälik korrektsemalt välja?

\section{Materjal ja meetod}

Materjal on kogutud lugemiseksperimentidega, mille käigus paluti keelejuhtidel ette lugeda 56 lauset, mis sisaldasid $42 h$-algulist sõna ja 30 (C)VVC-struktuuriga $i$-tüvelist sõna. Lugemiseksperimente on tehtud 2015. aastast alates ja praeguseks on kogutud materjali 194 keelejuhilt üle Eesti. Materjali salvestamise põhimõtteid ja käiku on üksikasjalikumalt kirjeldanud Kalvik ja Piits (2015). Siinse artikli tarvis tegime sellest materjalist valiku. Salvestised segmenteerisime ja märgendasime, kasutades programmi Praat (Boersma ja Weenink 2014). Lisaks sõna- ja häälikutasandile lõime programmis nii sõnaalgulise $h$ kui ka palatalisatsiooni jaoks lisatasandid. $h$ puhul piiritlesime lisatasandile vastava segmendi ning kui häälik kuuldelise mulje ning helilaine vaatluse järgi puudus, tähistasime selle märkega $h 0$. 
(C)VVC-struktuuriga $i$-tüvelistes sõnades piiritlesime lõpukonsonandi, mille märgendasime vastavalt kuuldelisele hinnangule palataliseerituks või mittepalataliseerituks (vrd paat' vs. paat). Pärast märgendamist kasutasime Praati skripte, et automaatselt leida, kui tihti $h$ või palataliseeritud konsonant oli välja hääldatud ning kui pikk oli sõnaalgulise $h$ kestus väljahääldamise korral.

\subsection{Sõnaalguline $h$}

Sõna alguses asuva $h$ analüüsimiseks võtsime uurimusse kõik senini märgendatud salvestised ehk 94 keelejuhi materjali. Igalt keelejuhilt oli $42 h$-algulist sõna, v.a kolm juhtu, kus keelejuht oli jätnud sõna lugemata või oli lugenud soovitud sõna asemel midagi muud. Sõnade hulgas olid enamjaolt ainsuse nimetavas käändes olevad nimija omadussõnad, määrsõnad ja neli erinevat verbivormi. Valdavalt olid need omasõnad. Kokku võtsime vaatluse alla 3945 hääldusjuhtu. Uurimaks sõna esinemissagedust varieerumise mõjutajana moodustasime sõnapaarid, kus üks paariline oli suure ja teine väikese esinemissagedusega sõna. Andmed lemma esinemissageduse kohta (vt tabelis 1) võtsime sagedussõnaraamatust (Kaalep ja Muischnek 2002), mis põhineb miljonisõnalisel ilu- ja ajakirjanduskorpusel. Sõnavalikul lähtusime sellest, et nii sagedates (esinemiskordi korpuses 88-2178) kui ka harvades (esinemiskordi korpuses 0-15) sõnades järgneks $h$-le sama vokaal. Selliseid sageduse alusel vastanduvaid $h$-alguliste sõnade paare oli 14, esimesena on esitatud suure esinemissagedusega sõna, järgneb väikse esinemissagedusega sõna: hakkas (hakkama kindla kv. lihtm. ains. 3. p.) - hakke (hakk 'vareslane' mitm. os.), hing - hingus, hästihädine, hiljem - hilpe (hilp mitm. os.), hindas (hindama kindla kv. lihtm. ains. 3. p.) - hingestatult, homme - homaar, hotelli (hotell ains. om.) hotentoti (hotentott ains. om.), hunt - huupi, heida (heitma käskiva kv. oleviku ains. 2. p.) - heldima, haigus - halastus, hind - hindu, hammas harras, hoolimata-hoomamata, hirm-hirss.

$h$ eristab tähendusi sõnades hais (vs. ais), hall (vs. all), hirve, hirv ains. om. (vs. irve), haru (vs. aru), harutama (vs. arutama), hõng (vs. ong), halastus (vs. alastus), harva (vs. arva, arvama käskiva kv. oleviku ains. 2. p.), hala (vs. ala), hea (vs. ea, iga ains. om.), hind (vs. ind). Selleks et lugejal tekiks selgem vastandusvajadus, paigutasime viis $h$-algulist sõna samadesse lausetesse koos vokaalialgulise sõnaga. 
Põõsa all kasvas pruun punakas seen, mitte hall.

Ma saan väga hästi aru, kuhu selle tee haru viib.

Enne ma arutasime, kuidas võiks vanu hilpe kasutada ja kampsuneid üles harutada.

Meie nooruslik ind rauges, sest selle asja hind jäi äärmuslikult kõrgeks.

Õng käes kõndisin mere poole, kui mulle lõi vastu soolane hõng ning nõiduslik hingus.

Sõnaalgulise $h$ uurimiseks arvutasime välja kõigi sõnade $h$ keskmise kestuse ja $h$ väljahääldamise protsendi. Võrdlesime nimetatud näitajaid sageduse alusel vastanduvates sõnapaarides, et selgitada välja, kas suurema esinemissagedusega paarikus on $h$ enamatel kordadel välja hälldatud ja pikema kestusega. Seejärel võrdlesime tulemusi suuremate rühmade kaupa. Sõnarühmi oli kokku neli: harva esinevad ja sageli esinevad sõnad ning sõnad, kus $h$ eristab tähendusi, ja sõnad, kus $h$ ei erista tähendusi. Arvutasime iga sõnarühma kohta $h$ keskmise kestuse ning $h$ väljahääldamise protsendi, et võrrelda omavahel sageduse alusel ning tähenduseristuse alusel vastanduvaid sõnarühmi. Rühmadevaheliste statistiliste erinevuste testimiseks rakendasime sõltumatute valimite $t$-testi, kasutades selleks Exceli ja StatPaci ${ }^{3}$ vahendeid.

\subsection{Palatalisatsioon (C)VVC-struktuuriga $i$-tüvelistes sõnades}

Palatalisatsiooni uurimismaterjaliks olid 40 keelejuhi ühesilbilised pika vokaaliga $i$-tüvelised sõnad. Nendes sõnades oli pikk vokaal $a a$, $o o, u u$ või ee ning nad lõppesid kas $l$-i, $n$-i, $s$-i, $d$ või $t$-ga, mis peaksid ÕS 2018 alusel olema hääldatud palataliseeritult. Kasutasime uurimismaterjali, mille põhjal käsitleti lõpukonsonantide palatalisatsiooni varieerumist keelejuhi päritolupiirkonnast lähtuvalt (vt Piits ja Kalvik 2019). Valimis esindas iga ajaloolist murdeala võrdne arv keelejuhte, kes olid pärit samast piirkonnast kui nende vanemad. Igalt keelejuhilt oli 15 sagedusel vastanduvat sama silbiriimiga sõnapaari, esikohal suure esinemissagedusega sõna, seejärel väikse esinemissagedusega sõna: saal - raal, plaan - paan, vaas - paas, laad - raad, paat - raat, veenjeen, peet-neet, kool-mool, toon-foon, roos - oos, noot-toot,

3 StatPaci programmi vt https://www.statpac.org/. 
kuul - pruul, pruun - uun, kruus - luus, pruut - nuut. Sõnade hulgas oli nii oma- kui ka võõrsõnu, kõik nad olid ainsuse nimetavas käändes.

Kuigi palatalisatsioon on eesti keeles olnud ajalooliselt koartikulatoorne nähtus, on see aja jooksul saanud ka tähendust eristava ülesande (Teras ja Pajusalu 2014: 259). Palataliseeritud häälik eristab kirjakeele normi järgi tähendusi meie uurimuse seitsmes (C)VVC-struktuuriga $i$-tüvelises sõnas: noot' 'noodikirjamärk' (vs. noot 'kalapüügivahend'), kruus' 'tass' (vs. kruus 'killustik'), kool' 'õppeasutus' (vs. kool 'ila'), kuul' 'kerakujuline ese' (vs. kuul, kuu ains. alalü.), kood' 'kokkuleppeline märk' (vs. kood, kuduma kindla kv. oleviku ains. 2. p.), tees' 'juhtmõte' (vs. tees, tee ains. seesü.), toon' 'värvitoon' (vs. toon, tooma kindla kv. oleviku ains. 1. p.), luus' (vs. luus, luu ains. seesü.). Lausetes, mida keelejuhid ette lugesid, esines enamasti ainult $i$-tüveline sõna, seega ei olnud lauseid lugedes võimalik näha otsest vastandust esitatud sõnapaaride vahel, vaid vastandus oli mõtteline.

Kokku oli mõlemas vastanduses olevaid (C)VVC-struktuuriga $i$-tüvelisi sõnu 37, nende häl̈ldusjuhte 1280 . Siingi oli sõnarühmi neli: harvade ja sagedate sõnade rühmad ning rühmad, kus palatalisatsioonil oli tähendust eristav funktsioon ja kus tähendust eristav funktsioon puudus. Arvutasime, mil määral (\%) sõnu rühmades palataliseeriti, et võrrelda omavahel sageduse alusel ning tähenduseristuse alusel vastanduvaid sõnarühmi. Sageduse alusel vastanduvaid sõnu võrdlesime ka paaride kaupa: iga hääldatud sõnapaari puhul hindasime, kas keelejuht palataliseeris mõlemat sõna, jättis mõlemad sõnad palataliseerimata või palataliseeris ainult sagedat / ainult harvaesinevat sõna.

\section{Tulemused}

\subsection{Sõna esinemissagedus sõnaalgulise $h$ häälduse mõjutajana}

Kõigist 3945 hääldusjuhust hääldati 92\% juhtudel sõnaalguline $h$ välja. 
Tabel 1. $h$-algulised sõnad paaridena, nende sagedus, $h$ keskmine kestus (ms), standardhälve ja väljahääldamata $h$-de protsent.

\begin{tabular}{|c|c|c|c|c|c|}
\hline Sõna & $\begin{array}{l}\text { Sage (S) / } \\
\text { Harv (H) }\end{array}$ & $\begin{array}{c}\text { Esinemis- } \\
\text { sagedus }\end{array}$ & $\begin{array}{l}h \text { keskmine } \\
\text { kestus (ms) }\end{array}$ & $\begin{array}{l}\text { Standard- } \\
\text { hälve }\end{array}$ & $\begin{array}{c}h \text {-ta hääldatuc } \\
\text { juhud (\%) }\end{array}$ \\
\hline haigus & $\mathrm{S}$ & 94 & 71 & 23 & 3 \\
\hline halastus & $\mathrm{H}$ & 12 & 85 & 25 & 2 \\
\hline hakkas & $\mathrm{S}$ & 2178 & 62 & 22 & 18 \\
\hline hakke & $\mathrm{H}$ & 6 & 81 & 30 & 1 \\
\hline hammas & $\mathrm{S}$ & 148 & 74 & 30 & 5 \\
\hline harras & $\mathrm{H}$ & 6 & 101 & 34 & 0 \\
\hline heida & $\mathrm{S}$ & 258 & 58 & 20 & 3 \\
\hline heldima & $\mathrm{H}$ & 7 & 74 & 27 & 1 \\
\hline hiljem & $\mathrm{S}$ & 449 & 76 & 23 & 9 \\
\hline hilpe & $\mathrm{H}$ & 6 & 58 & 20 & 6 \\
\hline hind & $\mathrm{S}$ & 398 & 76 & 26 & 2 \\
\hline hindu & $\mathrm{H}$ & 0 & 78 & 33 & 2 \\
\hline hindas & $\mathrm{S}$ & 182 & 68 & 21 & 4 \\
\hline hingestatult & $\mathrm{H}$ & 0 & 54 & 29 & 35 \\
\hline hing & $\mathrm{S}$ & 302 & 69 & 28 & 4 \\
\hline hingus & $\mathrm{H}$ & 6 & 89 & 28 & 1 \\
\hline hirm & $\mathrm{S}$ & 184 & 74 & 26 & 6 \\
\hline hirss & $\mathrm{H}$ & 0 & 86 & 23 & 7 \\
\hline homme & $\mathrm{S}$ & 169 & 69 & 20 & 5 \\
\hline homaar & $\mathrm{H}$ & 0 & 97 & 41 & 7 \\
\hline hoolimata & $\mathrm{S}$ & 88 & 80 & 35 & 7 \\
\hline hoomamata & $\mathrm{H}$ & 15 & 89 & 36 & 9 \\
\hline hotelli & $\mathrm{S}$ & 146 & 61 & 20 & 13 \\
\hline hotentoti & $\mathrm{H}$ & 0 & 67 & 24 & 13 \\
\hline hunt & $\mathrm{S}$ & 115 & 64 & 22 & 17 \\
\hline huupi & $\mathrm{H}$ & 10 & 76 & 26 & 3 \\
\hline hästi & $\mathrm{S}$ & 488 & 56 & 13 & 36 \\
\hline hädine & $\mathrm{H}$ & 6 & 74 & 22 & 5 \\
\hline
\end{tabular}

Märkus. Sõnad on esitatud paaridena esinemissageduse alusel: S - sagedad sõnad, $\mathrm{H}$ - harvad sõnad. Viimane veerg näitab, kuivõrd sõnu ilma $h$-ta hääldati. Joonega ümbritsetud väärtused märgivad juhte, kus sagedamas sõnas on $h$ pikema kestusega või enamatel kordadel välja hääldatud kui harvemas sõnas. 
Esinemissagedusel vastanduvate sõnapaaride võrdlus näitas, et 14 paarist oli enamik ehk 12 sellised, kus suurema esinemissagedusega sõna algul olev $h$ oli lühemalt hääldatud kui väiksema esinemissagedusega sõnas. Neist 12 paarist olid kaks sellised, kus erinevus ei olnud suur: sage hind ( $h$ keskmine kestus $76 \mathrm{~ms}$, standardhälve 26) vs. harv hindu (78 ms, standardhälve 33) ning sage hotelli (61 ms, standardhälve 20) $v s$. harv hotentoti (67 ms, standardhälve 24$)$. Ka $h$-ta hääldatud juhtude protsent oli neis paarides ühesugune. Kuid esitatuile lisaks leidus ka kaks sõnapaari, kus olukord oli kestuse poolest eeldatule vastupidine. Nii oli sagedas sõnas hiljem sõnaalgulise $h$ kestus 76 ms ning harvas sõnas hilpe $58 \mathrm{~ms}$ (standardhälbed vastavalt 23 ja 20). Tähelepanuväärne oli paar hindas - hingestatult ( $h$ keskmised kestused vastavalt 68 ja 54 ms, standardhälbed 21 ja 29), kus oli märgatav erinevus ka $h$ hääldamata jätmisel: $4 \%$ juhtudest (sage hindas) vs. $35 \%$ juhtudest (harv hingestatult). Selliseid paare, kus $h$-ta hääldusjuhtude protsent oli vastupidiselt eeldusele harva sõna puhul suurem, oli teisigi, näiteks hirm - hirss, homme - homaar ja hoolimata - hoomamata. Neis oli erinevus siiski väga väike, paari protsendi vahemikus, ning keskmiste kestuste andmed olid ootuspärased.

Üksiksõnade kaupa $h$ keskmisi kestusi vaadates on näha, et suure esinemissagedusega sõnades oli $h$ enamasti lühem kui väikse esinemissagedusega sõnades. Kui $h$ keskmine kestus oli 74 ms (standardhälve 29), siis keskmisest lühema $h$ kestusega olid enamasti sagedad sõnad, kuigi ka kolmes harvaesinevas sõnas - hingestatult (54 ms), hilpe (58 ms) ja hotentoti $(67 \mathrm{~ms})$ - oli $h$ kestus keskmisest lühem. Keskmisest pikema $h$ kestusega olid enamasti harvad sõnad, kuid ootustele vastupidiselt oli $h$ pikem ka sõnades hind (76 ms), hiljem $(76 \mathrm{~ms})$ ning hoolimata (80 ms).

Kokkuvõtlikult näitas esinemissagedusel vastanduvate sõnade uurimine, et sagedamas sõnas oli $h$ kestus lühem (keskmiselt $68 \mathrm{~ms}$ ) ning harvas pikem (keskmiselt $79 \mathrm{~ms}$ ). Gruppide statistiliselt olulisele erinevusele viitab ka $t$-test: $t=9,642, d f=2414 ; p<0,0001$. Väikse esinemissagedusega sõnades jäeti $h$ välja hääldamata $7 \%$ hääldusjuhtudest ja suurema esinemissagedusega sõnades $10 \%$ hääldusjuhtudest, mis osutus statistiliselt oluliseks erinevuseks: $t=2,759, d f=2630 ; p=0,0059$. 


\subsection{Sõna esinemissagedus palatalisatsiooni mõjutajana}

Palatalisatsiooni ja sõna esinemissageduse seoseid analüüsides peaks vastanduse sage/harv asemel arvestama vastandusega tuttav/tundmatu. Kuigi keelejuhtidelt ei küsitud, kui hästi nad lausetes esinevaid sõnu tunnevad, eeldasime, et sellised harvem esinevad sõnad nagu raat, oos, mool, uun ja toot on lugejatele tundmatumad. Mõnel juhul möönsid ka lugemiskatses osalenud, et nad ei tea mõne sõna tähendust. Tahtsime välja selgitada, kas väiksema esinemissagedusega ja kuulajale eeldatavasti mitte nii tuttavate sõnade hääldamisel lõpukonsonanti pigem palataliseeritakse või jäetakse see palataliseerimata. Uuritavad suure esinemissagedusega sõnad olid saal, plaan, vaas, laad, paat, veen, peet, kool, toon, roos, noot, kuul, pruun, kruus ja pruut. Vastavad väikse esinemissagedusega sõnad olid raal, paan, paas, raad, raat, jeen, neet, mool, foon, oos, toot, pruul, uun, luus ja nuut.

Kõigi 1200 hääldusjuhu hulgas esines palataliseerimata sõnu 71\%, suure esinemissagedusega palataliseeritud sõnu oli $16 \%$ ja väikse esinemissagedusega palataliseeritud sõnu oli 13\%. Arvestades, et materjalis oli sagedaid ja harvaesinevaid sõnu võrdselt, oli näha, et suurema esinemissagedusega sõnu palataliseeriti kolme protsendi võrra rohkem.

Sageduse alusel vastanduvaid sõnu võrreldi ka paaride kaupa: iga häl̈ldatud sõnapaari puhul hindasime, kas palataliseeriti mõlemat sõna, jäeti mõlemad sõnad palataliseerimata või palataliseeriti ainult sagedat / ainult harvaesinevat sõna. Võrdlesime palatalisatsiooni sageduse alusel vastanduvate sõnapaaride kaupa. Jooniselt 1 on näha, et kõigist 600 sõnapaarist oli kõige rohkem selliseid, kus mõlemad paarid jäeti palataliseerimata (44\%), veidi vähem oli selliseid paare, kus palataliseeriti mõlemaid paarilisi (29\%). Kõigist sageduse alusel vastanduvatest paaridest moodustasid $16 \%$ need paarid, kus ainult sagedam paariline oli palataliseeritud, ja 11\% moodustasid need, kus ainult harvem esinev paariline oli palataliseeritud. $t$-test näitas, et sõnapaaride arv, kus ainult sage paarik on palataliseeritud, erines oluliselt sõnapaaride arvust, kus ainult harv paarik oli palataliseeritud: $t=2,368, d f=599$; $p=0,0182$. 


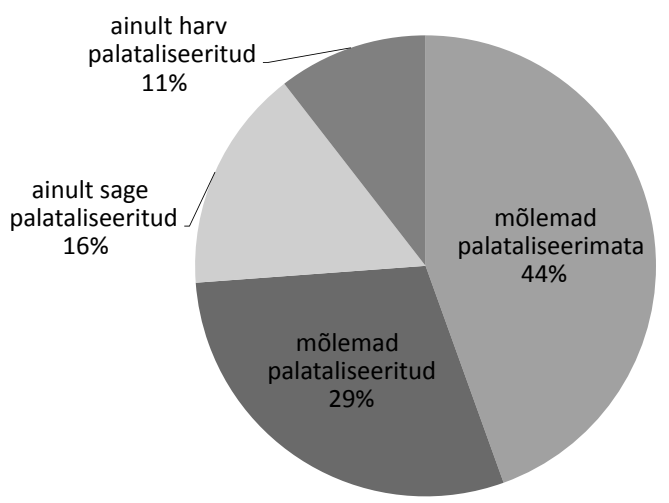

Joonis 1. Palatalisatsioon sageduse alusel vastanduvates sõnapaarides. Esitatud on sõnapaaride osakaal (\%), kus a) mõlemad paarilised on palataliseeritud, b) mõlemad paarilised on palataliseerimata, c) ainult sage paariline on palataliseeritud ning d) ainult harv paariline on palataliseeritud.

Siiski näitavad tulemused, et sõna esinemissagedus või sõna tuntus mõjutas keelejuhti vähe. Kui sõnapaarist palataliseeriti ainult üht paarilist, siis oli see pisut suurema tõenäosusega sage sõna, aga palju suurem oli võimalus, et palataliseeriti mõlemaid paarilisi või jäeti mõlemad paarilised palataliseerimata.

\subsection{Tähenduse eristamise vajadus sõnaalgulise $h$ häälduse mõjutajana}

Selleks et analüüsida tähenduse eristamise vajaduse mõju sõnaalgulise $h$ hääldamisele, võrdlesime nii $h$ väljahääldamist kui ka $h$ kestust tähendust eristavatel ja mitteeristavatel juhtudel. Tabelis 2 on $h$-algulised sõnad järjestatud alates sõnast harras, mille hääldamisel $h$-ta häl̈ldatud juhud puudusid, kuni sõnani $h a ̈ s t i$, mille hääldamisel jäeti $36 \%$ juhtudest $h$ hääldamata. Tabelist on näha, et sõnad, kus $h$ eristab tähendusi (hallil taustal), esinevad rohkem tabeli algusosas ehk nendes sõnades jäeti $h$ harva hääldamata. Teistest eristub tabeli lõpuosas paiknev sõna hirve, kus küll tähenduse eristamise vajadus võiks tingida $h$ esinemise, aga milles $h$ on jäetud välja hääldamata $19 \%$ juhtudest. 
Tabel 2. Sõnaalgulise $h$-ga sõnad järjestatuna $h$-ta hääldatud häl̈ldusjuhtude protsendi järgi.

\begin{tabular}{|c|c|c|c|c|}
\hline Sõna & $\begin{array}{c}h \text { tähendust } \\
\text { eristavas asendis }\end{array}$ & $\begin{array}{c}\text { Hääldus- } \\
\text { juhtude arv }\end{array}$ & $\begin{array}{c}h \text {-ta hääldatud } \\
\text { juhte }(\%)\end{array}$ & $\begin{array}{l}h \text { keskmine } \\
\text { kestus (ms) }\end{array}$ \\
\hline harras & - & 94 & 0 & 101 \\
\hline hall & + & 94 & 1 & 78 \\
\hline heldima & - & 94 & 1 & 74 \\
\hline hakke & - & 94 & 1 & 81 \\
\hline hingus & - & 94 & 1 & 89 \\
\hline hind & + & 94 & 2 & 76 \\
\hline hõng & + & 94 & 2 & 79 \\
\hline hea & + & 94 & 2 & 82 \\
\hline hai & + & 94 & 2 & 97 \\
\hline hindu & - & 94 & 2 & 78 \\
\hline holpsas & - & 94 & 2 & 84 \\
\hline harva & + & 93 & 2 & 69 \\
\hline halastus & - & 93 & 2 & 85 \\
\hline heida & - & 94 & 3 & 58 \\
\hline haigus & - & 94 & 3 & 71 \\
\hline huupi & - & 94 & 3 & 75 \\
\hline hais & + & 94 & 4 & 72 \\
\hline hala & + & 94 & 4 & 77 \\
\hline himur/a & - & 94 & 4 & 79 \\
\hline hindas & - & 94 & 4 & 68 \\
\hline hing & - & 94 & 4 & 69 \\
\hline homme & - & 94 & 5 & 69 \\
\hline hädine & - & 94 & 5 & 73 \\
\hline hammas & - & 94 & 5 & 74 \\
\hline haru & + & 94 & 6 & 77 \\
\hline hilpe & - & 94 & 6 & 58 \\
\hline hirm & - & 94 & 6 & 74 \\
\hline harutada & + & 94 & 7 & 74 \\
\hline hoolimata & - & 94 & 7 & 79 \\
\hline hirss & - & 94 & 7 & 86 \\
\hline homaar & - & 94 & 7 & 97 \\
\hline
\end{tabular}




\begin{tabular}{lcccc}
\hline Sõna & $\begin{array}{c}\boldsymbol{h} \text { tähendust } \\
\text { eristavas asendis }\end{array}$ & $\begin{array}{c}\text { Hääldus- } \\
\text { juhtude arv }\end{array}$ & $\begin{array}{c}\boldsymbol{h} \text {-ta hääldatud } \\
\text { juhte (\%) }\end{array}$ & $\begin{array}{c}\boldsymbol{h} \text { keskmine } \\
\text { kestus (ms) }\end{array}$ \\
\hline hiljem & - & 94 & 9 & 76 \\
hoomamata & - & 93 & 9 & 88 \\
hotelli & - & 94 & 13 & 61 \\
hotentoti & - & 94 & 13 & 67 \\
hunt & - & 94 & 17 & 63 \\
hakkas & - & 94 & 18 & 61 \\
hirve & + & 94 & 19 & 62 \\
hoia & - & 94 & 22 & 73 \\
hommikul & - & 94 & 23 & 60 \\
hingestatult & - & 94 & 35 & 52 \\
hästi & - & 94 & 36 & 54 \\
\hline
\end{tabular}

Märkus. Hallil taustal on sõnad, kus $h$ eristab tähendusi (tumehallil taustal sõnad, kus tähendusvastandus oli esindatud ka etteloetud lauses).

Sõnaalgulise $h$ väljahääldamata juhtude võrdlusest selgus, et sõnades, kus $h$ eristab tähendusi (11 sõna, kokku 1033 hääldusjuhtu), jäeti $h$ välja hääldamata $5 \%$ hääldusjuhtudest. Sõnades, kus $h$ ei erista tähendusi (31 sõna, kokku 2912 hääldusjuhtu), jäeti $h$ välja hääldamata $9 \%$ hääldusjuhtudest. $t$-test osutas, et tegu on olulise erinevusega: $t=4,082$, $d f=3943 ; p<0,0001$.

Vaatasime ka eraldi sõnu (hall, hing, hõng, haru, harutada), kus $h$ eristab tähendusi ja kus tähendusvastandus esineb ühes ja samas lauses (nt Ma saan väga hästi aru, kuhu selle tee haru viib). Nende sõnade hääldamisel jäeti $h$ välja hääldamata $4 \%$ esinemisjuhtudest. Seega tähendust eristaval juhul hääldati $h$ sõna alguses rohkem välja.

Sõnaalgulise $h$ keskmisi kestusi võrreldes selgus, et sõnades, kus $h$ eristab tähendusi (11 sõna, kokku 1033 hääldusjuhtu, neist $h$ välja hääldatud 982 juhul), oli $h$ keskmine kestus 77 ms (standardhälve 30) ja sõnades, kus $h$ tähendusi ei erista (31 sõna, kokku 2912 hääldusjuhtu, neist $h$ välja hääldatud 2650 juhul), oli $h$ keskmine kestus $73 \mathrm{~ms}$ (standardhälve 29). Kuigi statistiline erinevus oli $h$ kestustes olemas $(t=2,432, d f=3631 ; p=0,0076)$, ei olnud millisekundites mõõdetav erinevus nii suur, et saaks väita, nagu tähenduste eristamise vajadus tingiks $h$ kestuse olulise pikenemise. 


\subsection{Tähenduse eristamise vajadus sõnade palatalisatsiooni mõjutajana}

Siinses uurimuses on sõnu, kus minimaalpaari moodustavad nimetavas käändes sõnad: noot vs. noot', kruus vs. kruus' ja kool vs. kool'. Lisaks on uurimuses sõnu, kus minimaalpaari moodustavad erinevad sõnavormid: kuul vs. kuul', kood vs. kood', tees vs. tees', toon vs. toon ' ja luus vs. luus'. Võrdlesime, kas sõnu, kus palatalisatsioon eristab tähendusi, palataliseeritakse rohkem kui neid sõnu, kus nähtusel tähendust eristav funktsioon puudub.

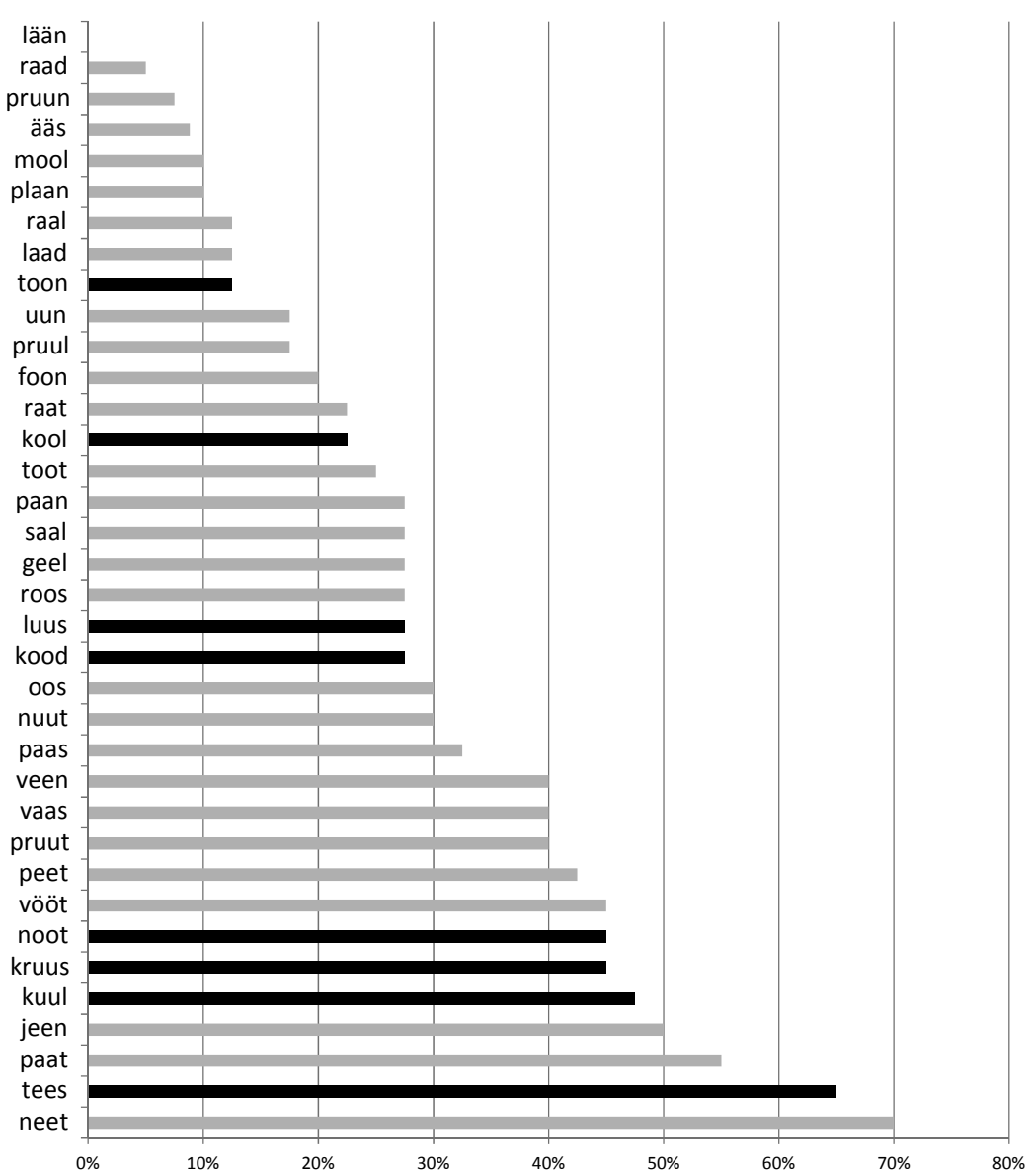

Joonis 2. Palataliseeritult hääldatud juhtude osakaal (\%) kõigist sõna hääldusjuhtudest. Mustad tulbad näitavad sõnu, kus palatalisatsioonil on tähendust eristav funktsioon. 
Jooniselt 2 on näha, et sõnade hulgas, kus palatalisatsioon eristab tähendusi, oli nii sõnu, mida palataliseeriti keskmisest enam (noot, kruus, kuul ja tees), kui ka sõnu, mida palataliseeriti keskmisest vähem (toon, kood, luus ja kood). Kõigi $i$-tüveliste sõnade hääldusjuhtude võrdlusest selgus, et sõnu, kus palatalisatsioon eristas tähendusi, palataliseeriti veidi enam ( $37 \%$ juhtudest) kui sõnu, kus palatalisatsioon ei eristanud tähendusi ( $27 \%$ juhtudest). $t$-test osutas, et tegu on olulise erinevusega: $t=3,469, d f=1438 ; p=0,0005$.

\section{Kokkuvõte ja arutelu}

Tulemused näitasid, et sõna esinemissagedus ja tähenduste eristamise vajadus mõjutasid mõningal määral $h$ hääldust ja $i$-tüveliste pika vokaaliga ühesilbiliste sõnade palataliseerimist. Sõna sagedus osutus oluliseks $h$ kestuse puhul, mõjutades mõõdukalt ka $h$ väljahääldamist, aga vähem sõna palataliseerimist. Tähenduste eristamise vajadus mõjutas rohkem sõnade palataliseerimist ja $h$ väljahääldamist, aga ei mõjutanud oluliselt $h$ kestust.

Selgus, et loetud kõnes hääldati $h$ välja $92 \%$ juhtudest. Kõrge väljahääldamise protsendi tingisid ilmselt lugemiseksperimendist tulenevad põhjused: mittespontaanne situatsioon (vt ka Asu et al. 2016) ja kirjapildi mõju hääldusele. Varasemad uurimused (Kalvik ja Piits 2015) on loetud kõnes täheldanud veelgi kõrgemat sõnaalgulise $h$ väljahääldamise protsenti (95\%), aga see võis tuleneda keelejuhtide valikust: nimetatud uuring põhines ainult 11 kõrgharidusega keelejuhi materjalil.

Tulemusi uurimisküsimuste põhjal analüüsides saab väita:

1. Esines tendents, et suurema esinemissagedusega sõnades on sõnaalguline $h$ lühem ja see jäetakse sagedamini välja hääldamata kui väiksema esinemissagedusega sõnades. See tendents avaldus rohkem sageduse alusel vastanduvate paaride juures. 14 sõnapaari võrdlusest selgus, et 12 puhul oli $h$ kestus suurema esinemissagedusega sõnas lühem. Erandina oli harvaesinevates sõnades hilpe ja hingestatult $h$ keskmine kestus lühem kui nende sagedamini esinevates paarilistes.

Kuigi etteloetud kõnes on olenemata sõna esinemissagedusest $h$ väljahääldamise protsent väga kõrge, kinnitas meie uuring varasemat tähelepanekut, et suurema esinemissagedusega sõnades on $h$ väljahääldamist siiski vähem kui väiksema esinemissagedusega sõnades (vt Cui 
1999: 42). Esines ka erandeid, kus $h$ hääldati väga tihti välja ka suure esinemissagedusega sõnades (hind, heida, hing ja hiljem), milles võiks eeldada selle hälaldamata jätmist. Samal ajal jäi mõnes väikse esinemissagedusega sõna vormis, nt hotentoti ja hingestatult, $h$ paljudel juhtudel välja hääldamata. Ilmselt võisid mitmed üldistele tendentsidele vastupidised juhud tuleneda muudest hääldust mõjutavatest faktoritest, näiteks häälikuümbruse mõjust, sõna pikkusest, paiknemisest lauses ja/ või rõhulisusest. Need faktorid võisid võimenduda, kuna samu sõnu on salvestatud samas kontekstis. Näiteks sõna hilpe esines küll 94 erineva keelejuhi esituses, aga kõik lugesid seda sõna samas lausekontekstis. Seega, kui sõna juhtus olema selles lauses rõhulises positsioonis või eelnes mõni häälikukombinatsioon, mis võis hääldust mõjutada, siis see mõju eeldatavasti võimendus.

2. Selgus, et väiksema esinemissagedusega, keelejuhile eeldatavasti tundmatumaid sõnu ei palataliseeritud oluliselt rohkem kui suurema esinemissagedusega sõnu. Sagedust on varasemates uurimustes seostatud eelkõige häälduskestuse lühenemise ja häälikukaoga (Bell et al. 2009, Bybee 2002 ning Coetzee ja Kawahara 2013), mis on häälduse ökonoomsusprintsiibist tingitud nähtused. Kuigi palatalisatsioon on ajalooliselt olnud koartikulatoorne nähtus, siis praeguseks pole (C)VVC-struktuuriga sõnades palatalisatsioon enam seotud keele ökonoomsusprintsiibiga. See võib olla põhjus, miks sõna esinemissagedus ei mõjutanud sõnade palataliseerimist.

3. Ilmnes, et sõnades, kus $h$ või palataliseeritud häälik eristab tähendusi, hääldatakse see korrektsemalt välja. Erinevused ei olnud aga suured. Sõnades, kus $h$ eristas tähendusi, hääldati see veidi sagedamini välja (95\% juhtudest) kui tähendusi mitteeristavatel juhtudel $(91 \%$ hääldusjuhtudest). Aga $h$ kestust tähenduste eristamise vajadus oluliselt ei mõjutanud: sõnades, kus $h$ eristab tähendusi, oli $h$ keskmine kestus neli millisekundit pikem kui sõnades, kus $h$ tähendusi ei eristanud. Sõnu, kus palatalisatsioon eristas tähendusi, palataliseeriti rohkem (37\%) kui sõnu, kus palatalisatsioon tähendusi ei eristanud (27\%).

Mõlema nähtuse puhul esines ka erandeid. Sõnavormis hirve jäi $h$ olenemata tähenduse eristamise vajadusest sagedamini välja hääldamata, kui oleks oodanud. (C)VVC-struktuuriga $i$-tüveliste sõnade hulgas oli näha, et sõnu toon, kood, luus ja kood, kus küll palatalisatsioon eristab tähendusi, ei palataliseeritud hoolikamalt. Põhjuseks võib olla, 
et minimaalpaari vahel olev tähendusopositsioon on teoreetiline ja lause lugemisel ei pruukinud tähendusvastandus keelejuhile üldse meenuda. Eriti juhul, kui tähendusopositsioonis sõna ka vormiliselt lausekonteksti ei sobi. Sõnades noot, kruus, kuul ja tees, kus tähendusvastandus võis olla ilmsem, palataliseeriti lõpukonsonanti rohkem. Sõna naabrustiheduse mõõtjad on samuti rõhutanud, et naabrustihedus on vaid teoreetiline näitaja ja pole selge, millised sõnad tegelikult kõneleja või kuulaja mentaalses leksikonis aktiveeruvad (Vitevitch ja Luce 2016: 7.3-7.4). Seega on võimalik, et mitmel juhul ei tajunud teksti lugeja üldse vajadust tähendusi eristada.

Edaspidi soovime uurida, mil määral mõjutavad sõnaalgulise $h$ hääldamist ning (C)VVC-struktuuriga $i$-tüveliste sõnade palatalisatsiooni esinemist sellised sotsiolingvistilised tegurid nagu keelejuhi vanus ja sugu. Keelelistest mõjutajatest vajab mõlema nähtuse puhul uurimist emfaas.

\section{Tänuavaldus}

Täname kõiki keelejuhte üle Eesti. Artikkel on valminud Eesti-uuringute Tippkeskuse (TK145-CEES), Haridus- ja Teadusministeeriumi uurimisprojekti IUT 35-1 „Kõnestiilid, lauseprosoodia ja fonoloogiline varieerumine: kirjeldus, teooria ja modelleerimine“ ning EKT projekti „Väljendusrikas ja mitmekesine kõnesüntees“ toetusel.

\section{Aadressid}

Mari-Liis Kalvik

Eesti Keele Instituut

Roosikrantsi 6

10119 Tallinn, Eesti

E-mail: mari-liis.kalvik@eki.ee

Liisi Piits

Eesti Keele Instituut

Roosikrantsi 6

10119 Tallinn, Eesti

E-mail: liisi.piits@eki.ee 


\section{Kirjandus}

Asu, Eva Liina, Pärtel Lippus, Karl Pajusalu ja Pire Teras (2016) Eesti keele hääldus. (Eesti keele varamu, 2.) Tartu: Tartu Ülikooli Kirjastus.

Bell, Alan, Jason Brenier, Michelle Gregory, Cynthia Girand ja Dan Jurafsky (2009) „Predictability effects on durations of content and function words in conversational English“. Journal of Memory and Language 60, 1, 92-111.

Boersma, Paul ja David Weenink (2014) Praat: doing phonetics by computer. [Arvutiprogramm]. Kättesaadav aadressil <http://www.praat.org > . Alla laetud 06.07.2014.

Bybee, Joan (2002), Word frequency and context of use in the lexical diffusion of phonetically conditioned sound change". Language Variation and Change 14, 3, 261-290.

Coetzee, Andries W. ja Shigeto Kawahara (2013) „Frequency biases in phonological variation“. Natural Language \& Linguistic Theory 31, 1, 47-89.

Cui, Kaily (1999) Sõnaalguline h eesti keeles. Bakalaureusetöö käsikiri Tartu Ülikooli eesti ja üldkeeleteaduse instituudis.

Kaalep, Heiki-Jaan ja Kadri Muischnek (2002) Eesti kirjakeele sagedussõnastik. Tartu: Tartu Ülikooli Kirjastus.

Kalvik, Mari-Liis ja Liisi Piits (2015) „Lugemiseksperiment fonoloogilise varieerumise uurimiseks". Eesti ja soome-ugri keeleteaduse ajakiri (erinumber Kõneuurimise suundi) 6, 3, 49-77. https://doi.org/10.12697/jeful.2015.6.3.02

Mesipuu, Margit (2007) Sõnaalguline h. Magistritöö käsikiri Tartu Ülikooli eesti ja üldkeeleteaduse instituudis.

Mäearu, Sirje (2014-2018) „Täheortograafia“. Veebiväljaanne Eesti õigekeelsuskäsiraamat. Tallinn: Eesti Keele Instituut. Kättesaadav aadressil

$<$ https://keeleabi.eki.ee/vikieksport/Taheortograafia.html>. Vaadatud 03.07.2019.

Piits, Liisi ja Mari-Liis Kalvik (2019) „Palatalisatsioon ühesilbilistes $i$-tüvelistes pika vokaaliga sõnades. Roos närtsis, sest vaas oli tühi“. Keel ja Kirjandus 7, 513-533.

Teras, Pire ja Karl Pajusalu (2014) „Palatalisatsioonist ja prepalatalisatsioonist spontaanses eesti keeles“. Keel ja Kirjandus 4, 257-269.

Vitevitch, Michael ja Paul Luce (2016) „Phonological neighborhood effects in spoken word perception and production“. Annual Review of Linguistics 2, 7.1-7.20.

ÕS $2018=$ Eesti oigekeelsussõnaraamat ÕS 2018. Tallinn: Eesti Keele Sihtasutus.

\section{Abstract. Mari-Liis Kalvik and Liisi Piits: Word frequency and a meaning-distinguishing function of a phoneme as a reason for variation.} The article investigates the variation of word-initial $/ \mathrm{h} /$ and palatalization in $i$-stemmed monosyllabic words with a (C)VVC structure. Two possible causes of the variation were examined: word frequency and meaning-distinguishing function of a phoneme. Material was collected by means of a reading task. The text consisted of words with both the word-initial $/ \mathrm{h} /$ and palatalized consonants. Altogether, 5225 pronunciations were analysed. The results show 
that: a) in $92 \%$ of occasions the word-initial $/ \mathrm{h} /$ was pronounced; b) in high frequency words, the word initial $/ \mathrm{h} /$ was shorter or absent more often than in low frequency words; $\mathrm{c}$ ) the word-initial $/ \mathrm{h} /$ in a meaning-distinguishing position tended to be more often pronounced and to be longer; d) consonant palatalization in $i$-stemmed words with a (C)VVC structure did not depend significantly on word frequency; and e) in the words where palatalization had a meaning-distinguishing function, the palatalized consonant was slightly longer than in the words where the function did not exist.

Keywords: Estonian, word-initial /h/, palatalization, reading experiment, word frequency, meaning-distinguishing function, duration 